\title{
Seismic Risk and Disaster Management Perspectives in Hungary, Presented on a Case Study Performed in Győr
}

\author{
Orsolya KEGYES-BRASSAI, ${ }^{1}$ Richard P. RAY, ${ }^{2}$ Rajmund $\mathrm{KUTI}^{3}$
}

Recent earthquakes with high number of casualties and enormous devastation have recently pushed engineers and designers to adopt preventive approaches to seismic safety. Vulnerability to earthquakes has increased due to extending urban areas. Seismicity in the Pannonian Basin is moderate compared to seismicity of surrounding areas, nonetheless, based on the recent high quality of earthquake observations, epicentre determinations have shown specific regions where earthquakes occur repeatedly. Moderate seismicity does not necessarily equate to moderate damage from earthquakes. Reports of major earthquakes often refer to heavy building damage and liquefaction (e.g. 1763 Komárom eq.). To reduce the potential damage, a comprehensive assessment of the seismic risk followed by a package of relevant remedial measures is needed. This paper presents the case study for the city of Györ, focusing on the local soil effects performing response analysis with more than 6,000 realizations and visual screening of more than 5,000 buildings to determine the vulnerability and the overall seismic risk. Based on the results engineers can plan improvements of the infrastructure easier, and authorities are able to make better plans for emergency activities in case of a seismic event.

Keywords: seismic risk, disaster management, local site effect, visual screening

\section{Introduction}

Preventive (pre-event) approaches have received greater attention recently since post-event evaluation methods are effective only in areas of regular seismic activity. Research in earthquake hazard mitigation has focused on evaluating possible damage scenarios for different magnitude events. [1] [2]

Hungary has experienced destructive earthquakes in the past; the most significant was the event of 1763 in Komárom with an estimated intensity of IX and an intensity of VII-VIII in Győr according to the European Macroseismic Scale. [3] Although such events are very rare, their intensity is comparable to the major earthquakes such as the Northridge earthquake (California 1994) with an MMI intensity of IX (equivalent to IX in EMS), being the second costliest disaster in US history after Hurricane Katrina. [4] [1]

Associate professor, Széchenyi István University, Department of Structural and Geotechnical Engineering, e-mail: kegyesbo@sze.hu.

2 Full professor, Széchenyi István University, Department of Structural and Geotechnical Engineering, e-mail: ray@sze.hu.

3 Associate professor, Széchenyi István University, Department of Mechatronics and Machine Design, e-mail: kuti.rajmund@sze.hu. 


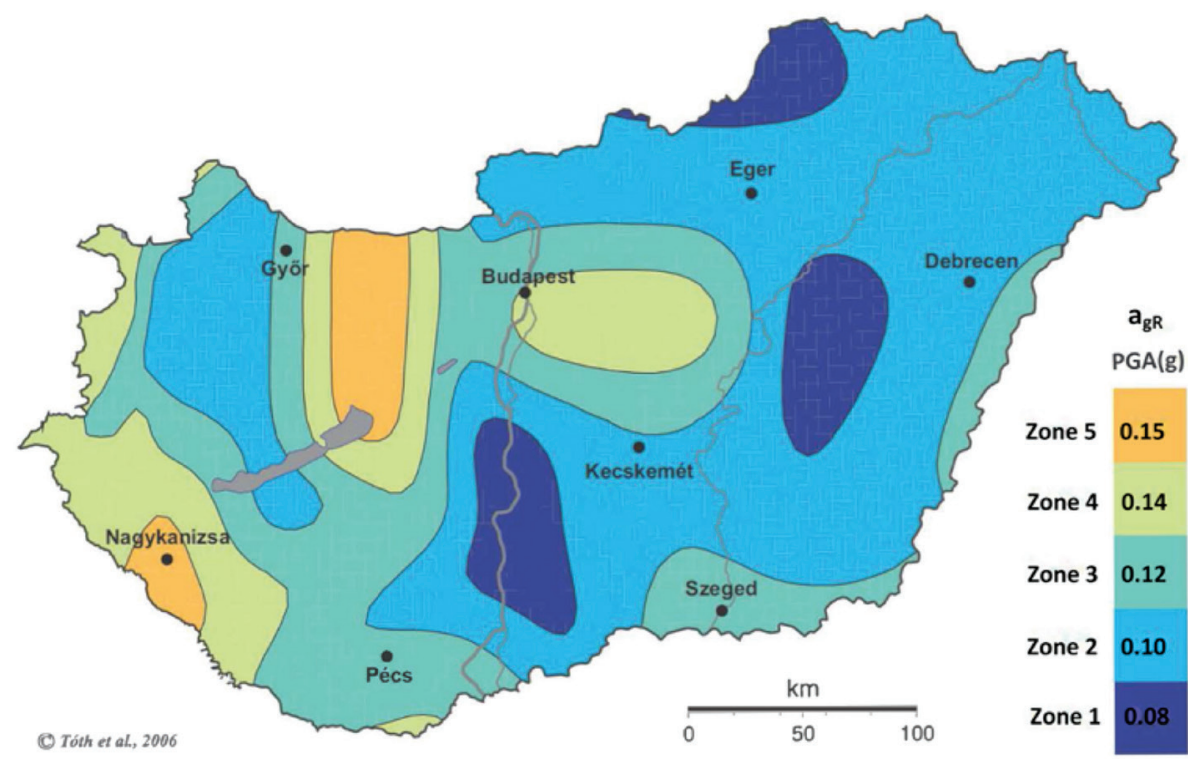

Figure 1. Peak horizontal accelerations from a seismic event that would occur once in 475 years (or a $10 \%$ probability of occurring in 50 years). [5]

The goals of the paper are: to present the process of seismic risk evaluation of a town; to integrate local site effects to previously determined seismic hazards (Figure 1) [5]; to examine the vulnerability of the built environment focusing on residential and public buildings; and finally, to combine the results and map risk scenarios to aid in the mitigation process.

The designated area to perform seismic risk assessment is Győr, being the sixth largest city of Hungary with an important regional economic and political role. Since no major damaging earthquake has occurred in Győr recently, vulnerability functions from observed damage patterns are not available. Therefore, a simple and fast evaluation method is proposed suitable for the assessment of local soil effects and evaluation of a large number of buildings.

\section{Seismicity of the Studied Area}

The seismicity of the Pannonian region is moderate. Earthquakes causing light damage occur every year, while stronger, more damaging magnitude 5 quakes happen about every 20 years and the return period of magnitude 6 events is about 100 years. [6] The focal depth of earthquakes is between 6 and $15 \mathrm{~km}$ below ground level in the region. The distribution of earthquakes is diffuse; however, there are certain areas where the occurrence is more concentrated, e.g. at the surroundings of Komárom-Mór-Berhida, known as Móri-trench. The hazard map of Hungary (Figure 1) illustrates this region of higher seismicity that is just west of Győr, running north-south. Aerial distance between Győr and the Móri-trench is about $60 \mathrm{~km}$. Historical data show that major earthquakes of this area had significant effects on buildings, causing damage not only in Komárom, but also in Győr.

The largest earthquake in Hungary occurred in the city of Komárom on June 28, 1763 with an estimated magnitude of 6.3, there were 63 casualties in Komárom and 4 in Győr. 
Overall more than 100 victims were reported. The taller (2-3 story high) ecclesiastic and noble buildings with more complex structure, typical for that age, suffered serious damage, both in Komárom and Győr, while the buildings of common people with only a ground floor made of adobe and timber survived the quakes. [6] Remedial measures were applied after the earthquake: the construction of 2-3 story high buildings were forbidden. Based on the percentages: $24 \%$ of the buildings destroyed, $30 \%$ seriously damaged and $18 \%$ requiring reconstruction, the intensity can be assumed to be IX on the EMS (European Macroseismic Scale).

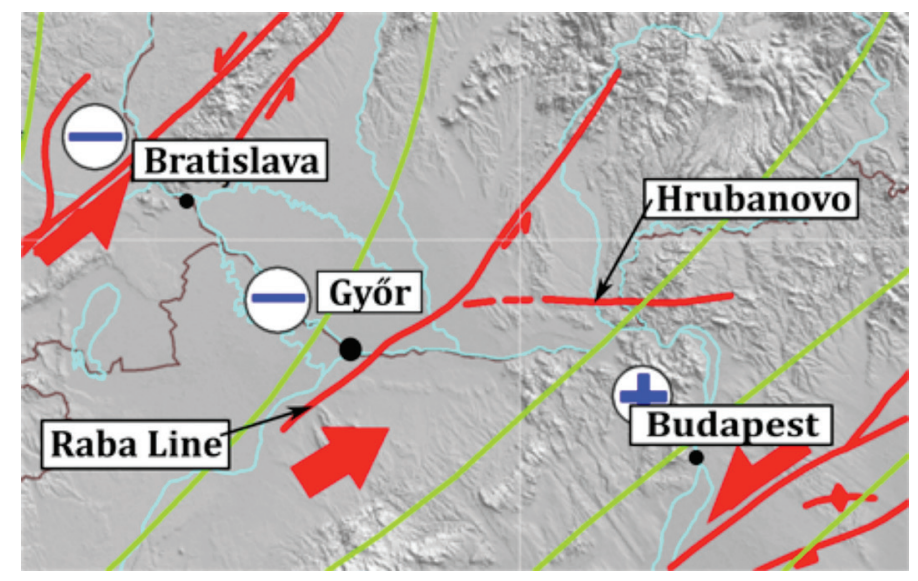

Figure 2. Neotectonics of Pannonian Region. [7]

Other significant faults contribute to the hazard concerning Győr. One of the lineaments lies beneath the Rába River, called Rába Line (Figure 2) and meets the Diósjenő-Őgyalla or Hrubanovo fault beneath the Danube River close to Győr. Recorded earthquakes with an epicentre at Győr mainly occur due to the above-mentioned faults.

\section{Microzonation of Győr}

Microzonation is the identification of separate individual areas having different potentials for hazardous earthquake effects. Seismic microzoning applies the local ground response, becoming a useful tool for cost effective risk mitigation. Detailed geological, geotechnical and structural evaluations are required for a realistic microzonation assessment. [8]

The severity of local ground motion depends on the magnitude and nearness of the source event, the ability for local geological conditions to focus or disperse energy coming from the source toward the region of interest, topographic factors and dynamic properties of near-surface sediments. At the source the depth, the initial frequency content of the vibration and the directionality of the fault release will influence intensity. The magnitude of an earthquake determines the potential damage level if a populated area is involved. Seismic hazard obtained by probabilistic (Probabilistic Seismic Hazard Analysis - PSHA) or Deterministic Seismic Hazard Assessment (DSHA) uses ground motion parameters with a given exceedance probability referenced to rock. That layer of the strata is considered rock in which the shear wave velocity is more than $700 \mathrm{~m} / \mathrm{s}$. [9] 
Seismic waves propagate through different geological formations affecting the characteristic of the waves, producing different effects on the ground motion at the ground surface, amplifying selectively different wave frequencies. It has been recognized that earthquake damage is generally larger over soft sediments than on firm bedrock outcrops. This is particularly important because most urban settlements have been built along river valleys over such soft surface deposits. The local topography can also modify the characteristics of waves, causing more damage to structures/buildings located at hilltops than those located in the valleys.

Soil effects and topographic effects are known as local site effects. Local site conditions describe the type of deposits that lie beneath the site. They are usually described in terms of shear wave velocity and sediment depth, representing physical quantities that can be related directly to the dynamic response of the underlying geological deposits.

One alternative to determine the effects of soil layers is to use the values of $v_{\mathrm{s} 30}$, the equivalent shear wave velocity that is the weighted average of shear wave velocities in the upper 30 meters. Soil profiles (SP) from the hydrogeological registers were used with the permission of the North Transdanubian Environmental Protection and Water Management Inspectorate. On the territory of the investigated area around 100 borings were available, from the 60 chosen hydrogeological registers originating from 1954 to 2008, with a depth varying between 25 and 2,155.7 m. The principle of selection was to cover adequately the study area with borings deeper than $30 \mathrm{~m}$.

The next step was to identify the dynamic properties of the different soil types. During the research Multichannel Analysis of Surface Waves was performed at 11 places close to the original borings of the hydrogeological registers. Compared to conventional borehole sounding tests, it is less expensive and provides the subsurface shear wave velocity profile over a large area. At four locations raw data from Cone Penetration Tests were offered by geotechnical companies, which ensured verification of the results. Calculation of $v_{s, 30}$ for each boring was performed based on three different methods. Based on shear wave profiles 15 zones (SP I to SP XV) were determined in Győr. (Figure 3)

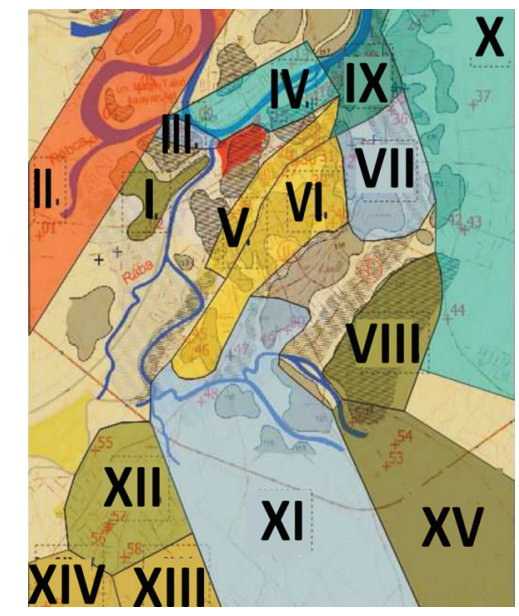

Figure 3. Zones with different soil profiles in Györ.

[Edited by the authors.] 
Using the different soil profiles (SP), one-dimensional site response analyses (Strata) [4] were performed by applying a suite of 7-10 different earthquake records to the base of the profiles fitting the general requirements of this region. Additionally, nonlinear behaviour models were applied to the different soil layers, based on our dynamic laboratory test results and correlations to other models. The software allowed to consider reasonable variations in soil properties and thicknesses of layers. In all, 6,000 realizations were generated.

The effect of the different soil zones on surface response were evaluated and the results were compared to the more uniform approach described in Eurocode 8. [10] While there was very general agreement with EC-8, there was also a great deal of variation in the level of seismic action due to the different soil profiles. (Figure 4) The responses were different enough to divide the city into different zones. Based on the careful examinations of spectral accelerations, shear wave velocities, amplification factors and soil profiles eight zones (C1-C6 and B1-B2) were defined in Győr. [11] The zonation with respect to spectral accelerations was mapped. (Figure 5) Soft transition boundaries were used to show the variation of the mapped parameters. More defined clear boundaries are not recommended. This allows some flexibility to the urban planners and avoids misinterpretation of clear boundaries as precise estimations of the different zones.
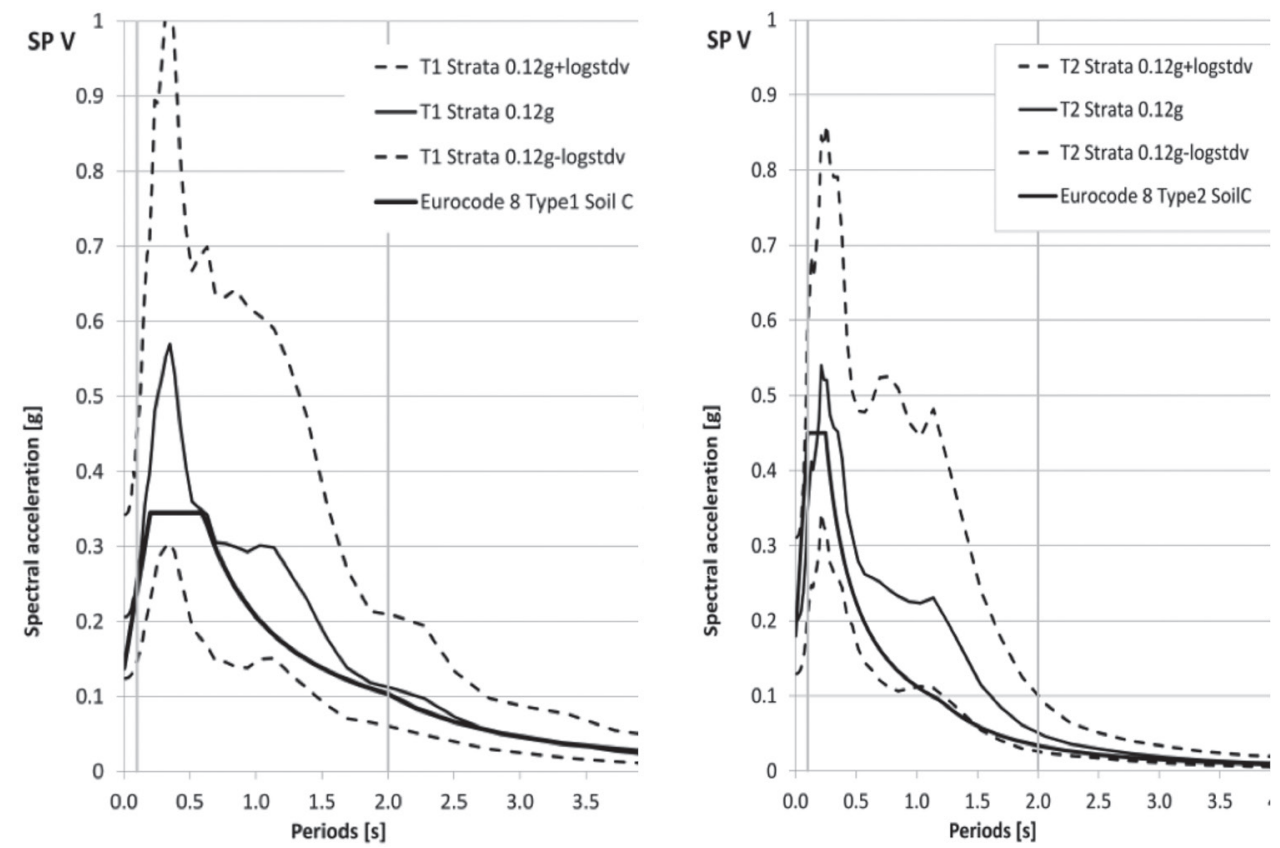

Figure 4. Comparison of average, $-1 \log$ and $+1 \log$ standard deviation results with Eurocode 8 design spectra (Type 1 and 2), used as seismic inputs in STRATA for comparison.

[Edited by the authors.] 


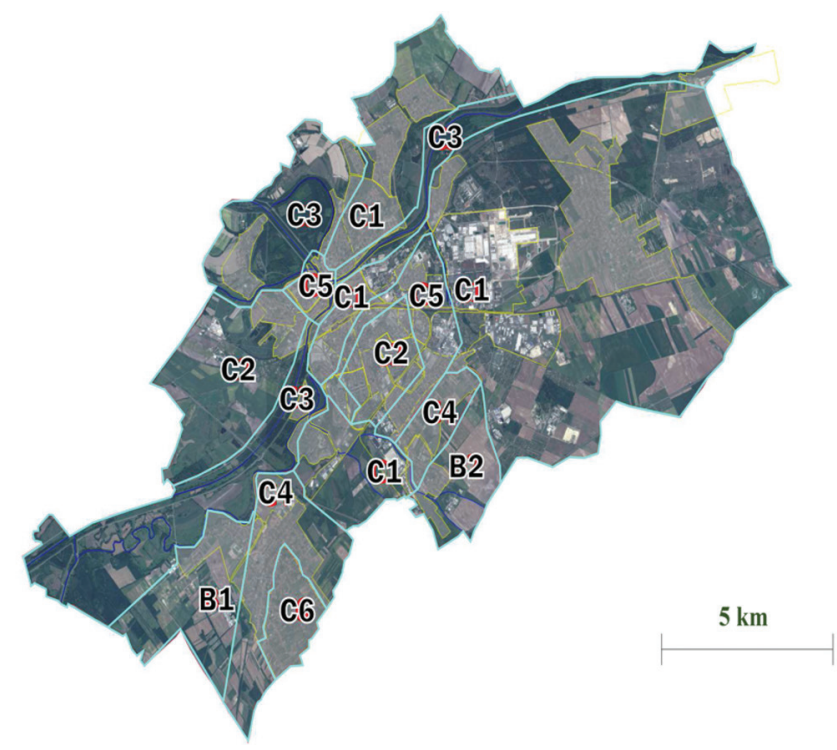

Figure 5. Microzonation of Györ (C1-C6 and B1-B2).

[Edited by the authors.]

\section{Vulnerability Assessment of Buildings}

Vulnerability is the possibility of damage or loss of structures due to a seismic event; it is the characteristic of the structures and it can be expressed in probabilistic or statistical terms. Vulnerability assessment is the process of identifying, quantifying and prioritizing (or ranking) the vulnerabilities in a system, and can be performed according to the following steps:

- cataloguing assets and resources in a system;

- assigning quantifiable value and importance to those resources;

- identifying the vulnerabilities or potential threats.

Vulnerability as an input parameter to earthquake scenarios requires evaluation of a large building population in a rather short period of time using a simple method, which describes the seismic performance of the buildings adequately. Vulnerability can be determined with the help of different methods. [12] The selection of the methods depends on the objective of the study, the required results and the available data, and can be grouped according to the space scale considered for analysis: e.g. urban level or building level, etc. [13] Large-scale approaches are based on empirical methodologies and local scale assessments are performed using some detailed numerical analyses. As these methods are getting more complex, they become more accurate, but also more expensive, requiring higher computational and evaluation efforts. Vulnerability assessment can be performed after or before an earthquake with different aims: either to determine retrofitting measures or to estimate expected damage for prevention purposes respectively.

Score assignment procedures aim to identify seismically hazardous structures by identifying structural deficiencies. The vulnerability index and screening meth- 
ods gather quantitative information by using vulnerability assessment forms, including parameters, such as quality of materials, type of foundations, number of stories, state of conservation, or stiffness of the structure. Depending on the parameter's value, a score is attributed to each feature to quantify the level of damage according to the severity of potential ground motion. [14] Potential structural deficiencies are identified from observed correlations between damage and structural characteristics. [15] [3] The objective of these procedures is to determine whether a particular building needs a more detailed investigation or not.

The rapid visual evaluation of buildings was performed on over 5,000 structures in Győr. (Figure 6) The evaluation method was developed from well-known approaches, [16] [2] [17] but modified to account for typical building designs found here. [11] The reliability of the visual evaluations performed by trained non-experts was verified by experts over a significant percentage of all buildings. Further evaluation of building vulnerability was performed by pushover analyses by simplified methods. The pushover analyses showed that the visual vulnerability assessments were consistent and reasonable.

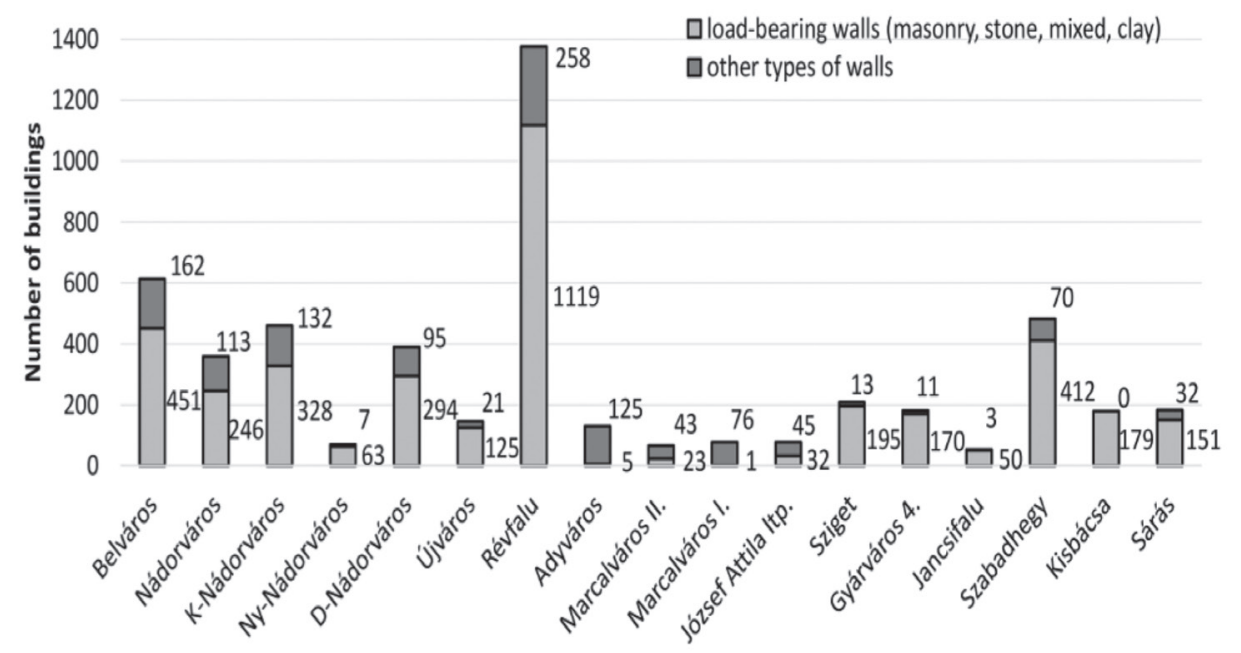

Figure 6. Dominant building types in Győr. Note the very high number of load bearing masonry wall structures.

[Edited by the authors.]

In order to determine the vulnerability throughout the city, city districts were divided into sections that each had a high percentage of one or two similar building types. This allowed for an accurate and rapid method to divide the risk assessment into manageable pieces. The evaluation process used about 25 sections within the city. Four districts were examined more closely. The zones differ from each other not only in location, but also in the types and the age of the buildings. For each building, a base score was determined due to structure based on FEMA 155. Score modifiers were taken into account, such as:

- vertical irregularity score modifier;

- construction code score modifier; 
O. KEGYES-BRASSAI, R. P. RAY, R. KUTI: Seismic Risk and Disaster Management Perspectives...

- score modifier concerning the height of the building;

- soil score modifier.

The construction time determined the level of seismic design used at the construction of each building. Based on the height of buildings two categories were taken into account: low-rise buildings with no modifier and mid-rise buildings. Vertical irregularity was based on the questionnaire.

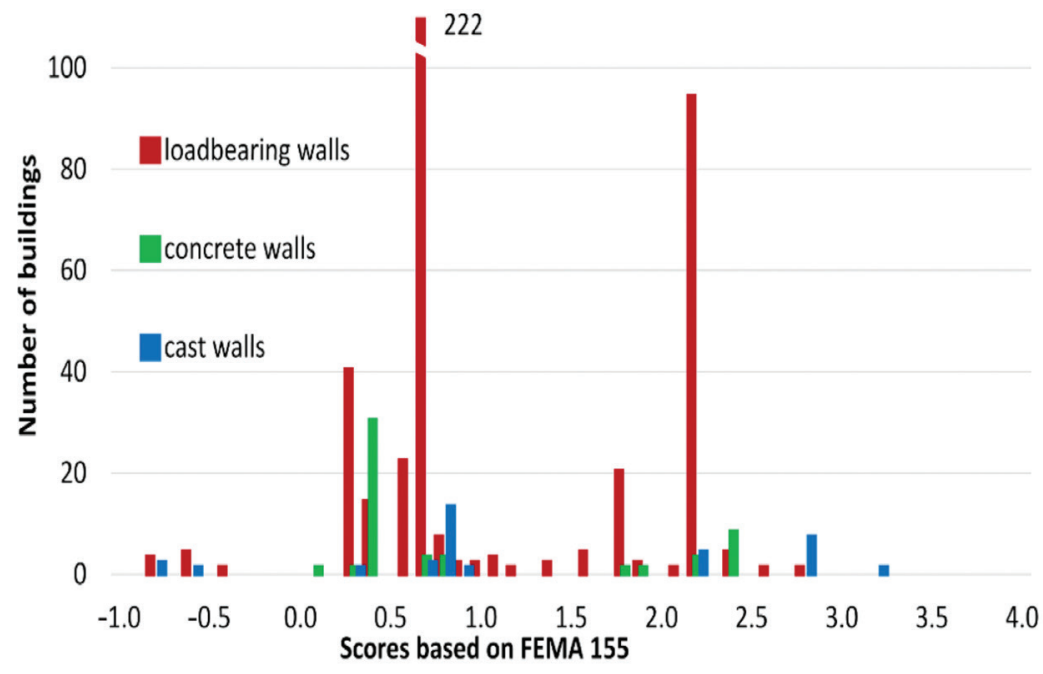

Figure 7. Scores with soil modifier in Belváros.

[Edited by the authors.]

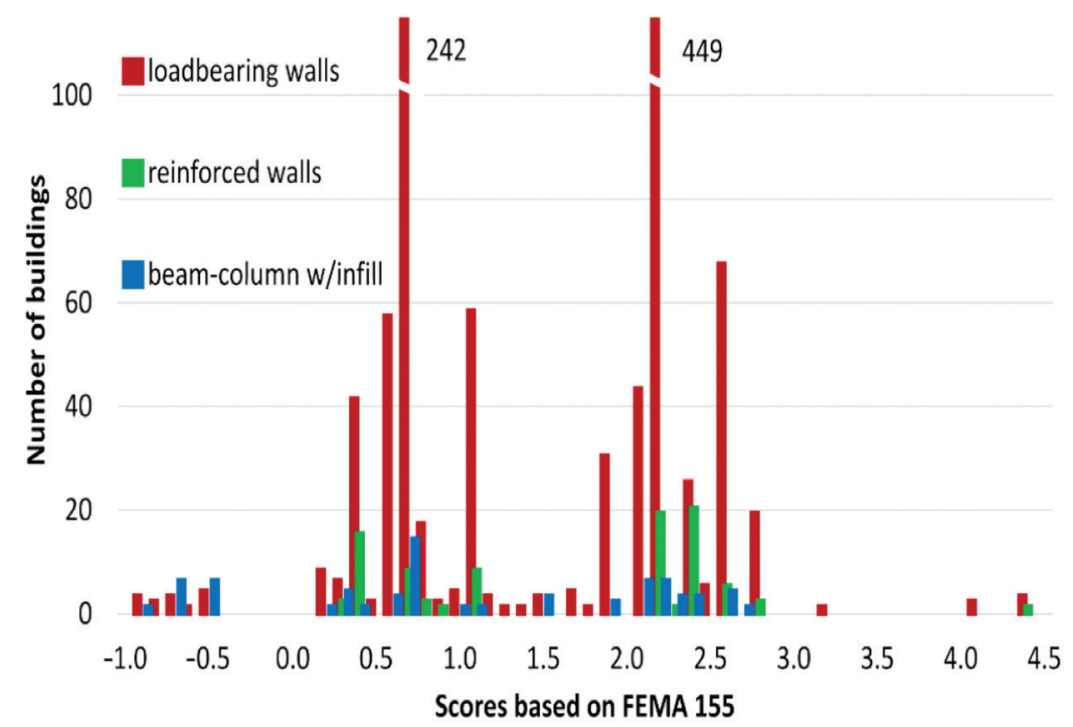

Figure 8. Scores with soil modifier in Révfalu.

[Edited by the authors.] 
Two sets of histograms represent first the score of the buildings with code, height and irregularity modifier and with the soil modifier (Figure 7 and 8) differentiating the most dominant building types. Masonry buildings dominate the final scores of the districts with two peaks: the lower score for the irregular buildings and higher for regular buildings. Lower scores represent higher risks.

\section{Seismic Risk to the City}

The city districts provide a good way to categorize building structures in general, since each district has a predominant building type and construction era. As shown earlier, there are over 5,000 buildings that have received scores. From an administrative view, mapping all would be problematic since evaluation, retrofit, repair and planning efforts would be applied by district or, perhaps, by sub-district.

Using a district approach is quite common in risk analysis; however, some decisions are necessary on how to assign a district score. One may pick a dominant structure type, either by building count or total resident occupancy. The average score for the dominant structure would then be applied to the district. Another approach is to use statistical methods to better describe the distribution of scores and the influence of different components of the hazard and vulnerability studies. For this study, both the dominant building approach and the average score approach produced essentially the same result. [11]

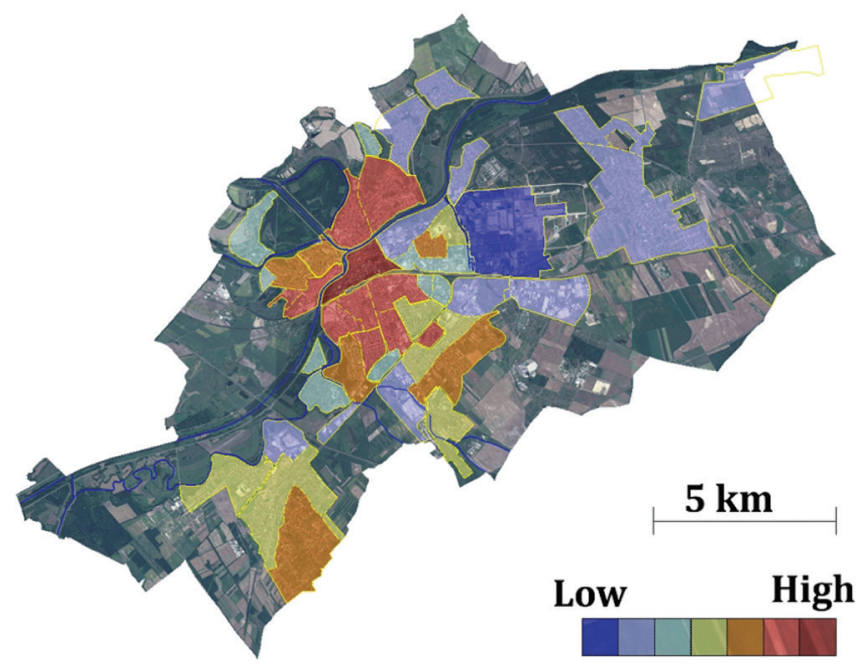

Figure 9. Relative seismic risk zones in Györ. Red is highest risk, blue is the lowest. [Edited by the authors.]

As Figure 9 demonstrates, highest risk is centred in Belváros, the old city centre because the buildings are old and the relative hazard is high compared to the other areas. The risk gradually reduces as one moves outward. Newer districts with better construction and variations in soil conditions are responsible for the reduction and pattern of risk values shown. Lowest risk factors are in the Gyárváros district where there are substantial buildings constructed 
according to newer codes and single free-standing homes having regular configurations. The risks shown are relative since the evaluation by rapid visual screening uses a score/ demerit system. However, in order to "anchor" these numbers and give definite recommendations, further detailed analyses of selected building types would be necessary.

\section{Earthquake Risk Management Perspectives Integrated into the Risk Management Plan of Győr}

The seismic hazard, vulnerability and earthquake risk is underestimated by both engineers and authorities or is not properly quantified as indicated in the next quotation, as stated on the homepage of Győr-Moson-Sopron County Emergency Management Directorate. "The county in terms of earthquake risk does not include itself among the hazardous counties. [...] it is therefore concluded that the county is not seismically hazardous, but definitely has to be considered”. [18]

Act No. CXXVIII of 2011, on disaster management and amending certain related acts declares that disaster management is a national matter and it is duty of the State and regulates the operation of the civil protection service and defence planning tasks of the cities. [19] Recently published National Emergency Risk Evaluation by National Directorate General for Disaster Management, Ministry of Interior based on the previously mentioned act adapts the results of the research about the seismic risk of Budapest. [20] Surprisingly it contradicts the former quoted statement of Győr-Moson-Sopron County Emergency Management Directorate, which definitely underestimates the seismic risk in Győr-Moson-Sopron County. [18] National Emergency Risk Evaluation suggests that microzonation of densely populated areas with higher values of assets should be performed, for example in case of county towns. This fact underlines the necessity of the hazard and vulnerability assessment of major cities (at least) and incorporation of the seismic risk assessment results in risk management plans of cities. Figure 10 presents the flowchart suggested to be incorporated into the Risk Management Plan (RMP) of City of Győr.

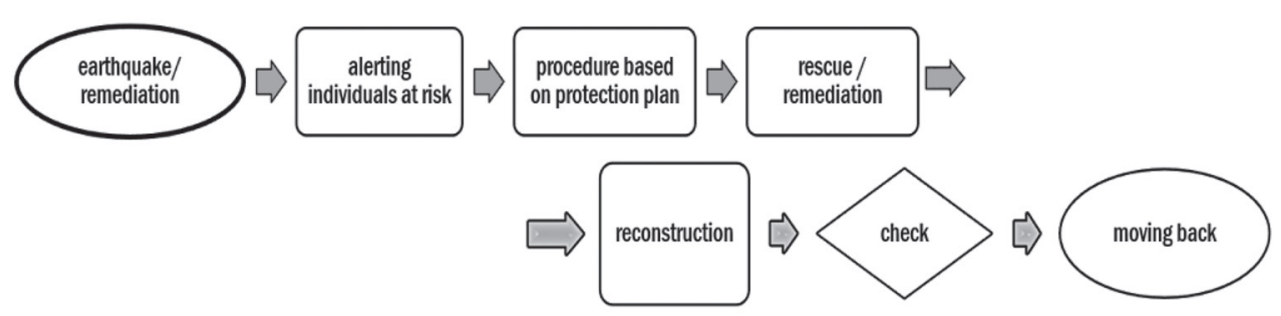

Figure 10. Suggested flowchart of the earthquake remediation procedure for RMP of Györ.

(Edited by the authors.)

The earthquake risk assessment results presented by this paper should be incorporated into the risk management plan of the city. Based on the seismic risk map of Györ, the exploration of endangered buildings would be easier and the population of identified higher-risk districts could be targeted with information more directly. The former evacuation and disaster plans should be modified concerning the rescue and remedial preparation setting priority of these 
O. KEGYES-BRASSAI, R. P. RAY, R. KUTI: Seismic Risk and Disaster Management Perspectives...

areas in order for rapid implementation of host sites and rescue vehicles to achieve a fast rescue of the population in the affected areas in case of a seismic event.

\section{Conclusion}

This paper presents a comprehensive approach for assessing seismic risk in a small city. The area is considered a moderate earthquake risk with past events, estimated up to $\mathrm{M}=6.5$. It is a typical situation for many cities in Hungary and throughout Europe where the seismic hazard is not great, but cannot be ignored. In order to make the best use of limited resources, the methodology used existing soil data, rapid visual building assessment, a limited number of field tests and free, but sophisticated software.

Variation in seismic hazard was evaluated mainly as a function of soil type. Using one-dimensional site response software, the impact of the different soil zones was evaluated and compared to the more uniform approach by soil type profile from Eurocode 8. The rapid visual evaluation of buildings was performed in Győr. The evaluation method was developed from well-known approaches, but modified to account for typical building designs found here. Estimates of seismic risk were computed using seismic hazard results and building vulnerability functions. As one would expect, since the hazards and vulnerabilities were not uniformly distributed around Győr, there were zones of higher and lower risk.

Based on these results, engineers and planners can decide where to improve buildings, whether to permit further development. The results provided by a seismic risk analysis could be regarded as helpful guidelines in respect to all the phases of the risk management: during normal periods, during crisis periods, as well as in the recovery and post-emergency periods, and can be directly applied into development plans, emergency planning, insurance calculation, etc. The method developed for the Hungarian context can be directly used to evaluate the earthquake risk of other cities.

\section{References}

[1] LUCO, N., ELLINGWOOD, B. R., HAMBURGER, R. O., HOOPER, J. D., KIMBALL, J. K., KIRCHER, CH. A.: Risk-Targeted versus Current Seismic Design Maps for the Conterminous United States. Squaw Creek: SEAOC Convention, 2007.

[2] FEMA 155: Rapid Visual Screening of Buildings for Potential Seismic Hazards: Supporting Documentation. $2^{\text {nd }}$ ed. Washington, D.C.: FEMA, 2002.

[3] FUKUYAMA, H., TUMIALAN, G., MATSUZAKI, Y.: Outline of the Japanese Guidelines for Seismic Retrofitting of RC Buildings Using FRP Materials. Cambridge: Non-metallic Reinforcements for Concrete Structures. FRPRCS-5. 2001.

[4] KOTTKE, A., RATHJE, E. M.: NEEShub - Resources: Strata. 2013. https://nees.org/ resources/strata (Downloaded: 1205 2013).

[5] GeoRisk Earthquake Engineering Ltd.: Seismic Hazard Map of Hungary. 2006. http:// georisk.hu/ (Downloaded: 0120 2014).

[6] VARGA P.: Az 1763. évi komáromi földrengés [The Komárom Earthquake of 1763]. Természet Világa, 1452 (2014), 69-72.

[7] BADA G.: A Pannon-medence jelenkori geodinamikája: Vizsgálati módszerek és kutatási 
O. KEGYES-BRASSAI, R. P. RAY, R. KUTI: Seismic Risk and Disaster Management Perspectives...

eredmények (Contemporary Geodynamics of Pannonian Basin: Test Methods and Research Results). Budapest: ELTE, 2005. http://geophysics.elte.hu/dolgozok/bada.htm\#oktatas (Downloaded: 0120 2014).

[8] ROCA, A., OLIVEIRA, C. S., ANSAL, A., FIGUERAS, S.: Local Site Effects and Microzonation. In. ROCA, A., OLIVEIRA, C. S., GOULA, X. (Eds.): Assessing and Managing Earthquake Risk. Dordrecht: Springer, 2006. 67-91.

[9] BISZTRICSÁNY E.: Mérnökszeizmológia (Engineering Seismology). Budapest: Akadémiai Kiadó, 1974.

[10] European Committee for Standardization: Eurocode 8: Design of Structures for Earthquake Resistance. MSZ EN 1998-1: 2004/A1:2013. Brussels, 2013.

[11] KEGYES-BRASSAI O.: Earthquake Hazard Analysis and Building Vulnerability Assessment to Determine the Seismic Risk of Existing Buildings in an Urban Area. Ph.D. dissertation, Győr: Széchenyi István University, 2015.

[12] CALVI, M. G.: A Displacement-Based Approach for Vulnerability Evaluation of Classes of Buildings. Journal of Earthquake Engineering, 33 (1999), 411-438.

[13] FOERSTER, E., KRIEN, Y., DANDOULAKI, M., PRIEST, S., TAPSELL, S., DELMONACO, G., MARGOTTINI, C., BBONADONNA, C.: Del. 1.1.1: Methodologies to Assess Vulnerability of Structural Systems. In. ENSURE (Enhancing Resilience of Communities and Territories Facing Natural and Na-tech Hazards). Project WP1: Stateof-the Art on Vulnerability Types. Eu. Com. $7^{\text {th }}$ FW Programme, 2009. 1-139.

[14] CALVI, G. M., PINHO, R., MAGENES, G., BOMMER, J. J., RESTREPO-VÉLEZ, L. F., CROWLEY, H.: Development of Seismic Vulnerability Assessment Methodologies over the past 30 Years. ISET Journal of Earthquake Technology, 433 (2006), 75-104.

[15] MOUROUX, P., BERTRAND, E., BOUR, M., LE BRUN, B., DEPINOIS, S., MASURE, Ph.: The European Risk-UE Project: An Advanced Approach to Earthquake Risk Scenarios. $13^{\text {th }}$ World Conference on Earthquake Engineering, Vancouver, B.C., 2004.

[16] FEMA 154: Rapid Visual Screening of Buildings for Potential Seismic Hazard. Washington, D.C.: FEMA, 1988.

[17] GRÜNTHAL, G. (Ed.): European Macroseismic Scale 1998. Luxembourg: European Seismological Commission, 1998.

[18] A megye veszélyeztetettségének elemzése. Győr-Moson-Sopron Katasztrófavédelmi Igazgatóság (Győr-Moson-Sopron County Emergency Directorate), 2014. http://gyor. katasztrofavedelem.hu/a-megye-veszelyeztetettsegenek-elemzese (Downloaded: 0423 2014).

[19] KUTI R.: Müszaki mentések I-II. (Technical rescue I-II.). Study material, Budapest: ZMNE, 2007.

[20] GYENES Z.: Nemzeti katasztrófakockázat-értékelés (National Disaster Risk Assessment). Budapest: National Directorate General for Disaster Management, Ministry of Interior, 2011. 